\title{
Tourism business operators' perceptions, knowledge and attitudes towards climate change at Victoria Falls
}

\begin{tabular}{|c|c|}
\hline \multicolumn{2}{|c|}{$\begin{array}{l}\text { Authors: } \\
\text { Kaitano Dube }{ }^{1} \\
\text { Godwell Nhamo }\end{array}$} \\
\hline \multicolumn{2}{|c|}{$\begin{array}{l}\text { Affiliations: } \\
\text { }{ }^{1} \text { Department of Ecotourism } \\
\text { Management, Faculty of } \\
\text { Human Science, Vaal } \\
\text { University of Technology, } \\
\text { Vanderbijlpark, South Africa }\end{array}$} \\
\hline \multicolumn{2}{|c|}{$\begin{array}{l}\text { 2Institute of Corporate } \\
\text { Citizenship, Faculty of } \\
\text { Economic Management } \\
\text { Sciences, University of South } \\
\text { Africa, Pretoria, South Africa }\end{array}$} \\
\hline \multicolumn{2}{|c|}{$\begin{array}{l}\text { Corresponding author: } \\
\text { Kaitano Dube, } \\
\text { kaitanod@vut.ac.za }\end{array}$} \\
\hline \multicolumn{2}{|c|}{$\begin{array}{l}\text { Accepted: } 27 \text { May } 2020 \\
\text { Published: } 27 \text { July } 2020\end{array}$} \\
\hline \multicolumn{2}{|c|}{$\begin{array}{l}\text { How to cite this article: } \\
\text { Dube, K. \& Nhamo, G., 2020, } \\
\text { 'Tourism business operators' } \\
\text { perceptions, knowledge and } \\
\text { attitudes towards climate } \\
\text { change at Victoria Falls', The } \\
\text { Journal for Transdisciplinary } \\
\text { Research in Southern Africa } \\
16(1) \text {, a } 778 . \text { https://doi. } \\
\text { org/10.4102/td.v16i1.778 }\end{array}$} \\
\hline \multicolumn{2}{|c|}{$\begin{array}{l}\text { Copyright: } \\
\text { (c) 2020. The Authors. } \\
\text { Licensee: AOSIS. This wc } \\
\text { is licensed under the } \\
\text { Creative Commons } \\
\text { Attribution License. }\end{array}$} \\
\hline \multicolumn{2}{|l|}{ Read online: } \\
\hline 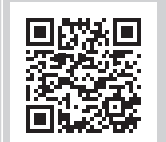 & $\begin{array}{l}\text { Scan this QR } \\
\text { code with your } \\
\text { smart phone or } \\
\text { mobile device } \\
\text { to read online. }\end{array}$ \\
\hline
\end{tabular}

Climate change remains one of the biggest challenges facing the world today and is characterised by extreme weather events such as heatwaves, extreme droughts and floods. Regardless of the threat posed by climate change to the tourism business, there are still gaps in tourism business perceptions and knowledge of climate change. This research investigated tourism business operators' perceptions, knowledge and attitude towards climate change at Victoria Falls. In this study that took a multidisciplinary approach, primary data were gathered using an online QuestionPro survey instrument and interviews. The survey was administered door-to-door to the identified 122 potential tourism business operators and other key stakeholders. A sample of 77 completed surveys (a 63\% response rate) was realised. The study found that there was a general understanding of the causes and impacts of climate change on the tourism business operators, even though the tourism industry was not taking full responsibility for its role in causing climate change. The respondents also cited challenges and barriers in dealing with climate change, including the lack of knowledge and finance, ignorance and a lack of technical capacity. Climate change was deemed to have caused disruption in tourism activities at Victoria Falls because of reduced water flow levels at the waterfall and the destruction of tourism infrastructure during extreme weather events. The research recommended improvement in climate change knowledge, climate financing and build capacity to help the tourism industry meet both the Sustainable Development Goals and commitments to the Paris Agreement.

Keywords: tourism business; perceptions; knowledge; climate change; Victoria Falls.

\section{Introduction and background}

Tourism is a significant economic sector globally and contributes to growth, employment and poverty reduction, especially in developing countries (Seetanah 2011:291). However, there are fears that the tourism industry is constantly under threat from climate change (Becken 2018:332). Tourism and climate change have a two-way relationship where the tourism industry is dependent on ideal climate conditions to allow for certain tourist activities to take place. Yet, tourism activities in the value chain result in harmful greenhouse gas (GHG) emissions that lead to climate change (Dube \& Nhamo 2019a:5). Most tourism activities would require an ideal temperature, certain wind conditions, cloud cover conditions and general fair-weather conditions. Activities such as beach going and game drives would require sunny weather conditions to take place (Georgopoulou et al. 2019:667; Matthews, Scott \& Andrey 2019:1). Winter Olympics, for example, would require sub-zero temperatures (Scott et al. 2019:1301).

Of critical concern in recent years has been the contribution of tourism to climate change and, indeed, the vulnerability of many tourism activities and tourism properties to climate variability and change. Scott (2011:17) argued that the tourism industry is ill-prepared to tackle the challenges posed by climate change, even though tourism is touted to have the most significant potential for climate change action in line with the dictates of Sustainable Development Goal 13 (Dube 2020:94). It is not clear why the tourism industry is lagging in meeting its climate change targets. This is particularly concerning as the industry's perceptions and knowledge of climate change remain scant, especially in the global South, where research in this area is still growing.

In recent years, few more perception studies have emerged to gauge how the various stakeholders understand climate change in this diverse industry with its many subsectors and role players. Of note, in Southern Africa, the following studies focused on various tourism stakeholders. Gössling et al. (2006:419) conducted a perception study on the impact of climate 
change on international travelling patterns. Hambira et al. (2013:19) and Mushawemhuka, Rogerson and Saarinen (2018:115) investigated nature-based tourism operators' perceptions on climate change impact and climate change adaptation. On the contrary, Hoogendoorn, Grant and Fitchett (2016:59) focused their perception study on the impact of climate change on two coastal areas of South Africa. Another perception study was conducted by Pandy and Rogerson (2018:104) focusing on tourism risk segments in South Africa. Dube et al. (2018:1) focused on tourist perceptions and how knowledge and attitudes shape travel and tourism behaviour in the Okavango Delta.

Regardless of the importance of perception studies, there are very few such studies in the diverse tourism industry (Mushawemhuka et al. 2018:117). It is our view that perceptions studies are essential in the climate change debate, more so in the tourism industry where there is a two-way relationship as indicated herein. The perception studies are essential in gauging knowledge on climate change and to help in evaluating the success of various initiatives being taken by the industry and its subsectors in addressing it. Mushawemhuka et al. (2018:118) argued that 'tourism operators' perceptions, preferences and decision-making has been noted as important in creating an understanding of how the tourism industry could aim to adapt to climate change impacts'. This view is also shared by Hambira et al. (2013:19) and (Becken 2013:55) who underscored the importance of perceptions studies in shaping policy, practice and knowledge of the impacts of climate change on the sector. Byg and Salick (2009) noted that:

[I]n order to effectively address climate change impacts at the local scale and to enable the process of adaptation, it is necessary to address a combination of perceptions, local variations, moral and spiritual interpretations, and locally relevant solutions. (p. 156)

Pandy and Rogerson (2018:104) reiterate that even though it is difficult for the tourism industry to conduct such studies, it will assist in informing climate mitigation and adaptation strategies into the future. Given the two-way relationship between tourism and climate change, Gómez, Armesto and Cors (2017:651) noted that perceptions and knowledge studies in the tourism climate space are important catalysts or barriers to climate action. This sentiment is also echoed by Pandy (2017) who indicated that:

[T]ourism-based perceptions remain a pivotal part of the decision-making process in the actions and plan surrounding adaptation to climate change. Such studies have, however, come to be dominated by research in developed countries in the global North, with relatively few studies investigating the perceptions of tourism businesses in the African tourism developmental context. (p. 8)

The tourism industry is often criticised for lacking the seriousness and technical capacity to tackle climate change and of being too focused on profit at the expense of the environment (Scott, Hall \& Gössling 2016b:13). Although this may be true, it is critical to note that regardless of the increase in the quantity and even quality of research into climate change in the academic space, such knowledge and insights may not be trickling down to an industry where it is utilised for decision-making. Therefore, this study examines tourism business operators and other role players' perceptions, knowledge and attitudes towards climate change at the Victoria Falls in Zimbabwe.

\section{Literature review}

There is an increasing consciousness of the strong link between tourism development and climate change (Byg \& Salick 2009:165). Michailidou, Vlachokostas and Moussiopoulos (2016:1) pointed out that tourism is a victim and a perpetrator of climate change. Tourism causes climate change through the emissions of GHGs. Yet, tourism is also affected by the impact of climate change through extreme weather events resulting from the changing climate, as highlighted earlier. The tourism industry produces significant GHG emissions from the hospitality industry, mainly through heating and cooling. Other significant GHG emissions are from the travel sector, which burns fossil fuels (Dube \& Nhamo 2019a:5; Tang, Zhong \& Ng 2017:704).

Under the business-as-usual scenario, the 2005 levels of GHG (interchanged with carbon) emissions from the tourism industry are set to grow by $130 \%$ by the year 2035 (Friedlingstein et al. 2014:711). This led some academics blaming tourism businesses for not doing enough to tackle climate change. Fears are that such growth in carbon emissions will exacerbate global warming and, consequently, the climate change challenge. Scott, Hall and Gössling (2016a:933) blame the growth in carbon emissions on the industry's lack of transparency and seriousness in dealing with climate change. Carbon emissions from the industry are expected to continuously increase at an annual rate of $3.2 \%$ compared with a required emission reduction of between $3 \%$ and $6 \%$ to achieve carbon-neutral growth (Peeters \& Dubois 2010:447). Such a trend could be attributed to several factors, amongst which is the lack of understanding of the dynamics of climate change (Pandy 2017:3). Gössling, Scott and Hall (2013:535) argued that the tourism sector is failing to monitor progress in its emissions targets, which makes it challenging to account or set industry targets.

The growth in carbon emissions is worrying, given the evidence that the tourism industry is particularly sensitive and vulnerable to climate change. This is so, specifically in Southern Africa where the industry is mostly dependent on right environmental conditions and ecotourism (Becken \& Wilson 2013:621; Dube \& Nhamo 2018:113). Extreme events, such as severe droughts, have been found to undermine ecosystem services disrupting wildlife tourism (Dube \& Nhamo 2020a:8; Mukwada \& Manatsa 2018:173). Other extreme weather events driven by climate change (Gössling et al. 2010:120), such as flooding, coastal inundation because of rising sea levels and severe rainfall events, have been found to damage tourism infrastructure and disrupt tourism activities and tourist movement globally (Perry \& Morgan 2017:6; Wilbanks, Fernandez \& Allen 2015:7). 
In Southern Africa, there have been concerns about the impact of climate change-induced droughts, which has disrupted the water flow. This has diminished the aesthetic values of the waterfalls at the iconic Victoria Falls during years of increasing extreme droughts (Dube \& Nhamo 2020b:41). In another study by Dube and Nhamo (2020c), drought emerged as having devastating effects on water-based tourism activities at the Kariba Dam. Droughts resulted in power interruptions for hospitality establishments, which have turned Kariba town into a ghost town during drought years. Kilungu et al. (2017:375) and Dube and Nhamo (2020a:1) found that droughts and flooding were increasing costs of running the Serengeti (Kenya) and Kruger (South Africa) national parks, respectively. Fitchett, Grant and Hoogendoorn (2016:112) noted that in the coastal Eastern Cape of South Africa, fears of rising sea levels were worrying tourism property owners. Snow tourism on Mount Kilimanjaro was also reported to be seriously under threat as global warming had caused severe snow declines which threatened slope stability, aesthetics and vegetation in the area (Hemp 2005:1013; Kilungu et al. 2019:235).

\section{Materials and methods}

Victoria Falls is one of the seven natural wonders of the world and a United Nations Educational, Scientific and Cultural Organization (UNESCO). It is also a Ramsar convention site that is located between the north-western tip of Zimbabwe and the southern border of Zambia along the Zambezi River. The Victoria Falls is an iconic global feature, which draws tourists from across the world. The rich biodiversity of this area has significant links with the tourist attractions of five different countries in the region, namely, Angola, Botswana, Namibia, Zambia and Zimbabwe. This eco-sensitive region is under threat of climate change, which can undermine the tourism product (Dube \& Nhamo 2019b:2027). The threat of increased incidence of climate change-induced droughts, reduced water flow along the Zambezi River and increases in temperature are worrying from a tourism perspective (Dube \& Nhamo 2019b:2027).

A mixed-method approach was used in this case. The case study allowed space for users to study the real-life phenomenon in their context (Norander \& Brandhorst 2017:117). A door-to-door questionnaire uploaded online on the QuestionPro platform was administered by the researchers targeting all tourism businesses operators in the resort town. The survey was conducted between April and December 2017. The researchers asked questions and completed the online survey tool that was developed before fieldwork. The questionnaire survey was administered using a tablet. Other tourism role players such as tourism experts, traditional and political leadership, civic organisations, government agencies and the United Nations (UN) agencies formed part of the survey, as tabulated in Figure 1. These critical stakeholders were involved because they provide a supportive role to the tourism industry, and some are involved in bylaws and climate policies that have a bearing on the tourism industry. Questions centred around their observations on the impact of climate change and observed response of the industry as part of triangulation of data. Participation in the research was voluntary and through informed consent. Key informant-guided interviews were used to complement and triangulate data (Marshall 1996:92).

The survey questionnaire was pretested with field experts in the community, and it was administered with internal consistency and inter-rater reliability of instrument scores (Kimberlin \& Winterstein 2008:2277). The questionnaire comprised a mixture of 18 open and closed questions. The questions were on selected and relevant demographic aspects; questions which tested knowledge on climate change, perceptions of causes of climate change and the impact it has on Victoria Falls tourism products; and the outlook of tourism, considering the impact of climate change.

The respondents were given a chance to reread the recorded response to ensure the credibility of the findings (Noble \& Smith 2015:34). The researchers identified 122 potential respondents, which included 100 registered tourism businesses in Victoria Falls. Forty-five respondents opted out during the survey, with 77 respondents realised as the final sample (63\% response rate). The QuestionPro was used to analyse all questions. A total of 33 interviews were granted. Interview data were transcribed and prepared for thematic analysis following the dictates of the qualitative data analysis. Further analysis of data was done using Microsoft Excel Analysis ToolPak.

\section{Ethical consideration}

Ethical approval to conduct the study was obtained from the University of South Africa (Ethical clearance number: 2016/ CAES/107) on 04 November 2016.

\section{Results and discussions}

This results section is divided into two main subsections. The first subsection covers the perceptions and attitudes of respondents towards climate change. The second subsection

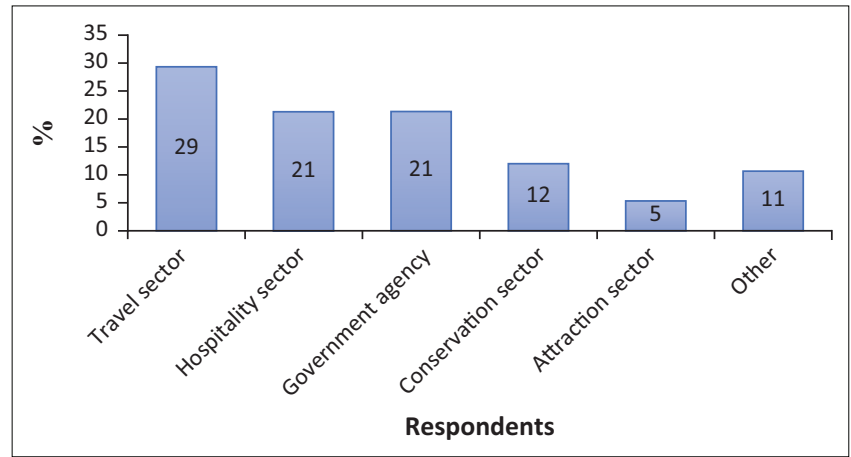

FIGURE 1: Respondents by sector $(n=77)$. 
focuses on the perceived evidence and the impact of climate change on Victoria Falls.

\section{Perceptions and attitudes towards climate change}

Climate change concern is believed to be a factor of experience, beliefs and perceived knowledge and is a central predictor of action (Prokopy et al. 2016:211; Shi et al. 2016:759). As such, the respondents were asked to rank their level of concern regarding climate change. It emerged that most respondents were concerned about climate change (Figure 2). An estimated $94 \%$ of the respondents were concerned about climate change to a certain extent, with only $6 \%$ indicating otherwise. The high levels of concern can be attributed to numerous extreme weather events such as droughts and increased incidences of heatwaves in the area over the past few years as observed by Dube and Nhamo (2019b:118). This means that most of the respondents are conscious of the challenges and unusual weather events attributed to climate change. The business community in the town believes that climate change is a real threat to the town's way of life. As such, there is potential to translate that into climate action.

In order to drive climate change action, it is imperative to review the views of the respondents regarding their perceptions of the causes of climate change. As such, the business community was asked to explain what they perceive to be the causes of climate change. It emerged that the majority of respondents $(69 \%)$ believe that climate change is anthropogenically driven. The findings show that the opinion is much higher than compared with global statistics. According to Schandl and Walker (2017:1), only 46\% of the global population believes that climate change is caused by human beings. The results from Victoria Falls may be attributed to the high levels of consciousness and concern for climate change as reported earlier. Eighteen per cent of the respondents believe that climate change is a consequence of natural processes. Most of those who indicated other causes (14\%) believe that climate change is caused by a combination of human and natural processes. The understanding that climate change is caused by human activities is critical for ascertaining accountability, addressing climate change, and drafting adaptation and mitigation strategies.

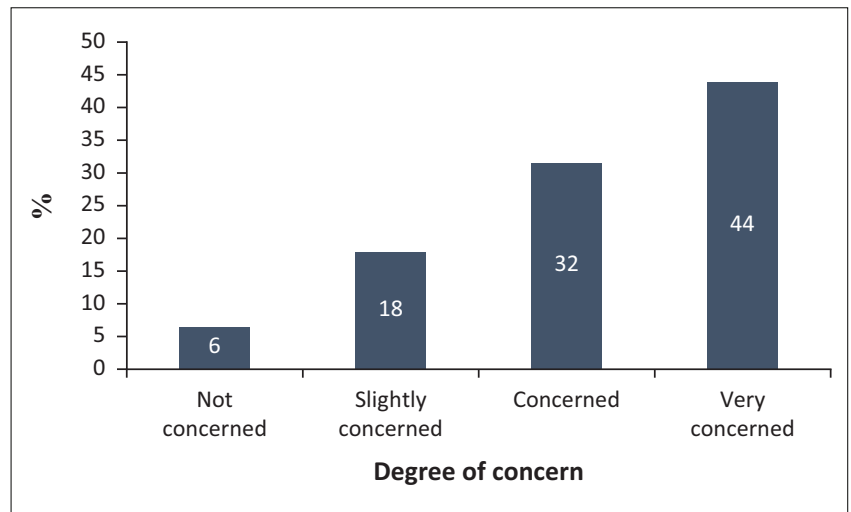

FIGURE 2: Climate change level of concern $(n=77)$.
It could be argued that the green tourism accreditation of 13 tourism businesses operating in and around Victoria Falls in 2016 was not a coincidence. Rather, this is an acknowledgement and understanding by the tourism industry that it is a contributor to the problem of climate change. Realisation and understanding are critical in fostering climate change action by the industry in line with the dictates of Sustainable Development Goal 13 (UN 2015). This argument resonates with the arguments by Gómez et al. (2017:287) on perception shaping climate action. It is not possible to wish away the contribution of the increased occurrence of extreme droughts and heatwaves in the area that have led to a severe reduction of water flow at the waterfall in some years. The tourism business on both sides of the Victoria Falls was negatively affected by the extreme droughts and heatwaves that affected the resort from 2014 to 2016 (Dube \& Nhamo 2019b:115).

Given the wide circulation and panic amongst tourists and ordinary citizens in 2014/2015 over the perceived drying of the waterfall, respondents were asked to give their opinion on the matter and prospects of the Victoria Falls drying up in the foreseeable future. About $54 \%$ said that the Victoria Falls would not dry up. However, $26 \%$ indicated that they believe the waterfall is drying up. This could be because of the 2015 drought, which led to a significant drop in water flow at the waterfall, especially in October and November between 2014 and 2017. The decline in the water flow could result in the waterfall drying up in those months if the trend continues in the near future or during the extreme drought period, according to findings by Dube and Nhamo (2018:117). One of four respondents indicated that they were not sure it would dry up because, in the absence of scientific data, it was challenging to state with accuracy. However, they had seen a growing trend of unusual water flow at the waterfall. Some years were punctuated by extremely high water flows, whereas in other years extremely low water flows were recorded. Respondents also indicated that this water flow pattern could be cyclic and called for scientific research to answer this question.

It can be argued that the figure of $54 \%$ of respondents believing that the Victoria Falls will not dry up is still a low figure regarding confidence and the perceived level of threat to the Victoria Falls. The fact that slightly more than half the respondents believe that the Victoria Falls is safe from drying up is a matter of concern and reveals the level of threat the world heritage site is exposed to. As such one can argue that the perception and level of threat from climate change are significant as seen from other world heritage sites of similar stature such as the Great Barrier Reef in Australia as noted by Wolff et al. (2018:1978).

Arguably, the high level of fear of extreme weather events could be one of the driving factors behind the increased diversification and increased tourism activity offered in the resort town. These include activities that are not necessarily dependent on water, such as special events, sporting activities, shopping experience, conferences and other adventure activities. This array of activities helps to 
act as buffers in years of extreme weather events in the vulnerable resort town.

The respondents were further asked to identify the top three organs they felt are central in dealing with the problem of climate change. Forty-five per cent (Figure 3) expected the government to play a leading role in addressing climate change. Whilst respecting the fact that climate change requires a combined effort, there is an expectation that local and national government should play a central role in the climate change space because they provide the policy and legal framework for dealing with climate change. In many settings, governments are responsible for downscaling climate change information and playing a central role in capacity building and building resilience and adaption for climate change (Nalau, Handmer \& Dalesa 2017).

Governments can assist in allocating funds for climate change, research funding and identification of areas of vulnerability. This gives credibility to the fact that dealing with climate change requires strong governance at the national and local levels. Be that as it may, business still needs to have more appreciation of its role in climate action if the fight against climate change is to be won. Business is the ultimate implementer of policies and can fund research and innovation in the quest against climate action. The lack of a clear policy on climate change by the Zimbabwean government for the tourism industry is, therefore, regrettable as it reduces movement in climate change action.

Almost a fifth of the respondents indicated those in business and industry as the second option in dealing with climate change. Business and industry have an essential role to play in climate change as part of the multi-stakeholder group that plays a central role in implementing mechanisms and mitigation strategies. The rules and ethos of globalisation that demand closer interaction between state actors and the private sector in the climate change debate and intervention remain valid. There is a need for the private sector to embrace ethical business practices, which are not detrimental to the environment. Many accounting standards require the inclusion of sustainability plans that respond to social and environmental issues (Kourula, Pisani \& Kolk 2017).

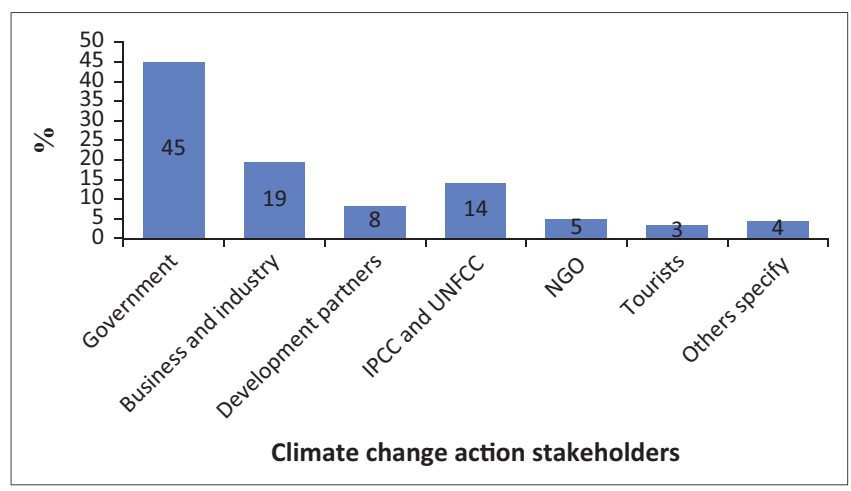

IPCC, Intergovernmental Panel on Climate Change; UNFCC, United Nations Framework Convention on Climate Change; NGO, non-governmental organisation.

FIGURE 3: Ranking of organs to deal with the problem of climate change $(n=77)$.
Because most respondents are business owners and managers, there is an understanding that, as a business, they have a crucial role to play in tackling climate change to ensure that mitigation and adaptation strategies are put in place. This could explain why some businesses in the resort town have embraced a green tourism initiative. The number of such businesses is still low, given the urgency that is required to address climate change by the tourism sector. Curtailing climate change will require every business entity in the resort town to be on board for significant contribution to mitigation and adaption.

However, only $4 \%$ of the respondents do not see tourists as critical players in addressing climate change. This may be as a consequence of a lack of knowledge or ignorance of the significant role of tourists in this regard. This is contrary to global calls that tourists should be major stakeholders in addressing climate change (Hindley \& Font 2018). As major stakeholders, tourists need to be included in carbon reduction and adaptation measures for climate change. The limited understanding of the role of tourists in dealing with climate change issues is demonstrated by the absence of initiatives targeted at tourists to participate in carbon-reduction initiatives in almost all establishments at Victoria Falls. The door-to-door survey revealed that only a handful of accommodation establishments are retrofitted buildings with energy and water-saving gadgets, and there were also no guidelines for tourists on responsible tourism practice.

When asked which three significant challenges were encountered in addressing the climate change issue, the respondents identified a lack of knowledge, followed by a lack of appropriate technology and the third challenge of ignorance and a lack of finance (Figure 4). A lack of networks and partnerships was identified as the least problematic in addressing climate change. The findings are not unique to the Victoria Falls community because studies elsewhere have found that knowledge gaps are a stumbling block in dealing with climate change efficiently (Liu et al. 2016:41). In the absence of climate change knowledge, it will be impossible for the tourism industry to meet its commitment under the Paris Agreement of carbon reduction of $70 \%$ by 2050 (Gössling \& Scott 2018:525). It is equally unlikely that the tourism industry will be able to meet Sustainable Development Goal 13 commitments (to take action to address climate change), which could prove to be dire. The tourism industry is blamed for contributing $5 \%$ of total global carbon emissions which drive climate change. This means that carbon emissions from the industry may continue to increase in the resort area confirming concerns that the industry will likely see a tripling of carbon emissions under business as usual (Gössling \& Scott 2018:2071). Dube and Nhamo (2019a) cast doubts on the capacity of the aviation industry on the Victoria Falls route to reduce its carbon emissions in the near future. There is, therefore, a greater need to close this knowledge gap by intensifying research and knowledge-sharing efforts through environmental education, workshops, campaigns and climate change roadshows. 


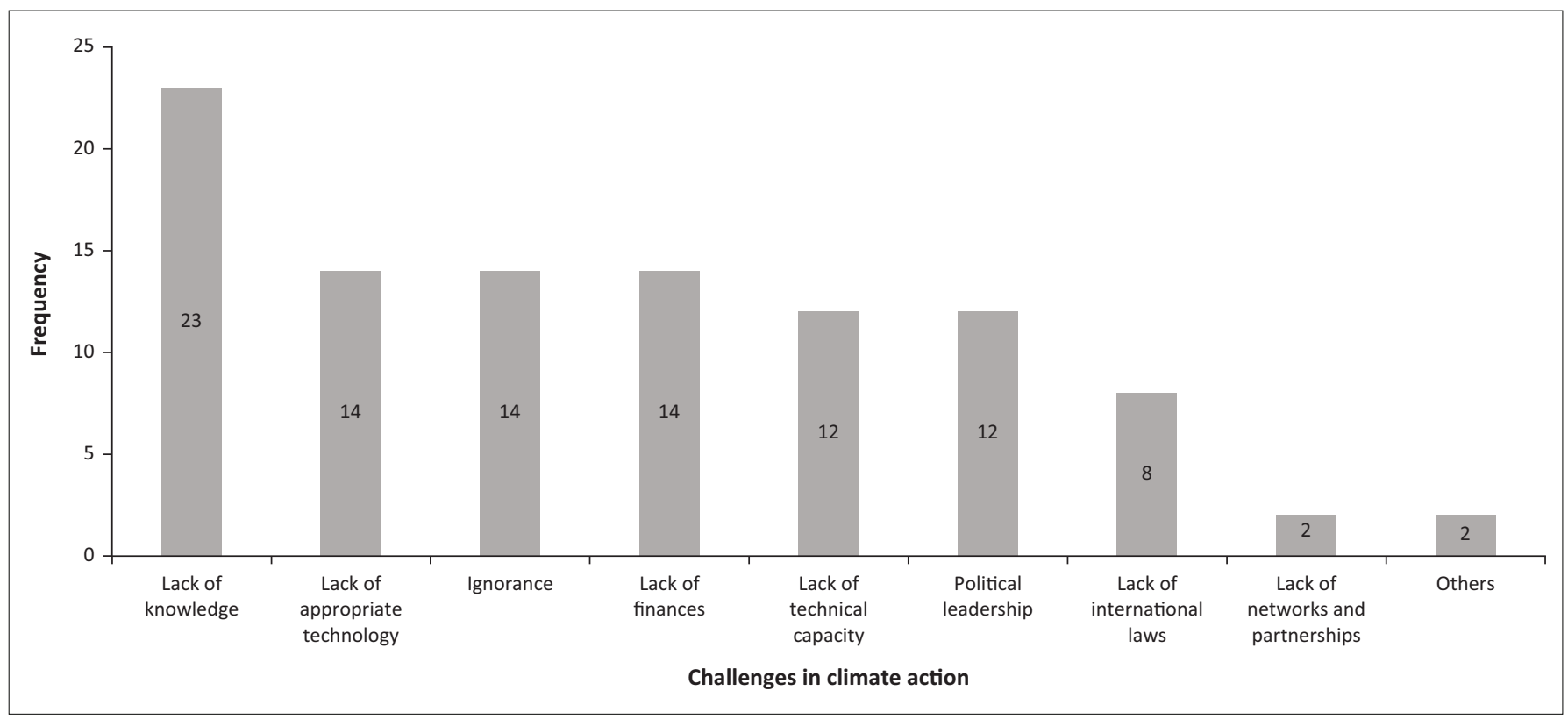

FIGURE 4: Challenges faced by tourism role players in dealing with climate change $(n=75)$.

Technological innovation and transfer play a central role in dealing with the climate change problem. To deal with climate change effectively, countries have to invest and conduct research and embrace local relevant technology that abates and reduces carbon emissions and assist with adaptation efforts. As a developing country with competing demands, it would appear that Zimbabwe and the business sector are struggling to innovate their business to an ecologically friendly technology that assists in either reducing their carbon footprint or adapting to the vagaries of climate change. Jiang et al. (2017:21) and Nishijima (2017:340) argue that dealing with climate change requires technological innovation. Such innovation must be tailored and designed around the notion of ecological civilisation and energy efficiency in a manner that reduces the carbon footprint. Scott et al. (2016a:9) noted that the tourism business lacks the technical capacity to address climate change as players in the industry have no technical capacity to measure their emissions, which makes it difficult for them to reduce their emissions.

It is not surprising that the lack of finance was cited as the second most significant obstacle in dealing with climate change. Climate financing is critical in enhancing both adaption and mitigation strategies, as noted by scholars such as Pandy (2017:104). Because of vulnerabilities and poor access to finance, there will be a need by global financiers to extend funding that is easy to assess and whose conditions do not inhibit uptake to finance climate initiatives such as green technology and retrofitting of buildings to make them more climate-smart to match the current and anticipated future climates. Some old tourism businesses could benefit from cheaper climate finances to ensure migration towards smart or green tourism.

\section{Perceived implications of climate change on the Victoria Falls}

The Victoria Falls community pays specific attention to the environment because it is the most significant source of livelihood for the resort town, either directly or indirectly. Changes in the biophysical environment affect life in the resort town in various ways. In the following paragraphs, discussions are presented on the impact of climate change on temperature, rainfall, the Zambezi River flow regime and wildlife.

\section{Impact of climate change on temperature and rainfall}

Temperature is a crucial weather element in Victoria Falls because it has a direct and indirect bearing on activities and tourism operations. Most respondents (76\%) were of the opinion that the Victoria Falls area had experienced some increase in temperature over the years (Figure 5), with October unusually hot. This confirms findings by Dube and Nhamo (2018:120) who observed a temperature increase of about $1^{\circ} \mathrm{C}$ in the last four decades. The research found that, because of increasing temperatures, activities such as elephant rides were now restricted to early mornings and evening hours to limit dehydration of visitors during hot afternoons. There is, therefore, an expected reduction in revenue from this activity because of shortened periods. However, respondents noted that during the day, tourists tend to participate in water activities such as white water rafting, fishing and swimming, which have a cooling effect on the human body. Notably, water activities are encouraged in the afternoon and early evening hours. The study also found that depending on the season, walking trails in the rainforest can be undertaken as well as adventure swimming in the Devil's Pool at the top edge of the Victoria Falls. 
Some businesses indicated that because of increased temperatures, they were forced to buy expensive air conditioners, fans, swimming pools and water fountains, thereby increasing business running costs because of increased water and energy use, especially during the summer months. It was common for hospitality establishments to ensure the comfort of guests, especially during the hot, humid summer months. The hoteliers and other hospitality players indicated that the demand for air conditioning was costly as it increased capital expenditure and operating costs at a time they were seeking to cut costs. Regardless of the challenges of electricity supply in Zimbabwe, the growing demand for electricity because of increased temperatures from climate change remains an opportunity to green power producers and the indirect employment in a country that is energy and job starved. They may have to re-engineer the buildings to make them heatproof and to reduce cooling needs.

The study also revealed that the demand for water during the peak dry and the hot season had gone up in recent years, which was attributed to increased evaporation rates from increased temperatures for animal and human-related activities. This resulted in increased water bills for companies and increased infrastructure development demands. Furthermore, it was reported that an increase in the demand for beverages and water was characteristic of hot days. The potential winners from this phenomenon were noted as local and international suppliers and vendors of bottled water and other cold beverages because of an increased demand associated with such weather conditions.

The summer temperatures were reported to be much warmer than before, which adversely affected most businesses in the area. The attraction sector indicated that an increase in temperature was problematic for animals in several ways. Firstly, tour operators and national park officials reported that, because of high temperatures, animals were staying in the shade for longer hours which made it difficult for tourists to see them when taken for game drives. This has the potential of affecting tourist satisfaction levels during the hot summer months. National park officials and private game owners further indicated that an increase in temperature meant an increase in animal water demand and

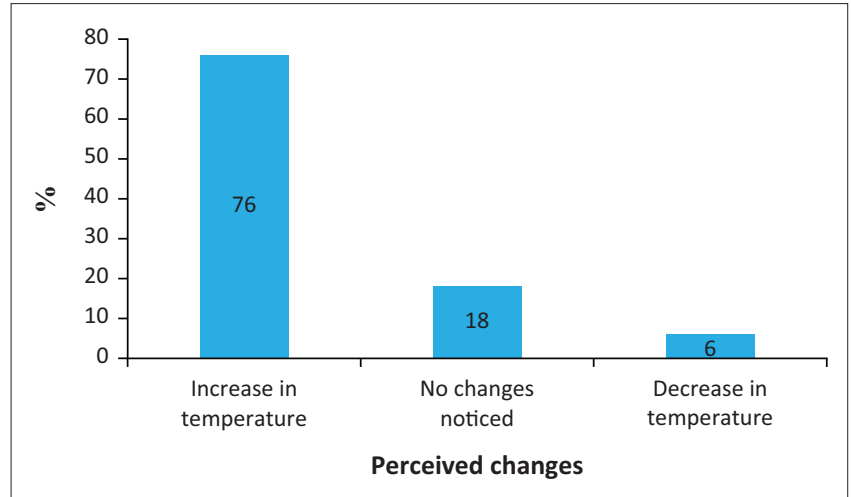

FIGURE 5: Perceptions of temperature changes $(n=67)$. fast drying of animal watering points. This increased their operating costs because they had to put extra measures in place to provide water for animals.

Park officials and tour guides noted that the high temperatures made it difficult to work outdoors because of the intense heat. They reported that even morning hours were now becoming increasingly hot, humid and uncomfortable. Tour operators indicated that some tourists were not keen to participate in activities when it was scorching hot and would cancel activities to stay in cool areas. A few respondents had experienced sunburn, and the fear was that this could affect the repeat visit plans for tourists.

Two of the three prominent helicopter companies complained that the ever-increasing temperatures in the area were disruptive to their operations of providing helicopter views of the Victoria Falls to tourists. Helicopter engineers and helicopter pilots indicated that they experience difficulties in the operational efficiency of the helicopters when temperatures rise above $35^{\circ} \mathrm{C}$, which has recently become a trend in summer.

The respondents were also asked to give their opinion on rainfall trends in the area over the years. About $59 \%$ indicated that they had noticed a general decrease in the rainfall amount in the area over the years (Figure 6). The considerable uncertainty could be a consequence of extremes of drought and heavy precipitation in the area, which makes it challenging to articulate what could be happening. The tourism players noted that this had varying impacts on tourism activities and products in the area. The respondents noted that a decline in rainfall over the years has resulted in a reduction in available food for animals and human beings in the area. Reduced food availability for animals was partly to blame for the reduced animal population in other areas. Reduced rainfall also triggered food inflation, and the operators reported that food shortages often led to increases in food prices for hotels, and this had a knock-on effect on the tourism value chain. The findings resonate with earlier

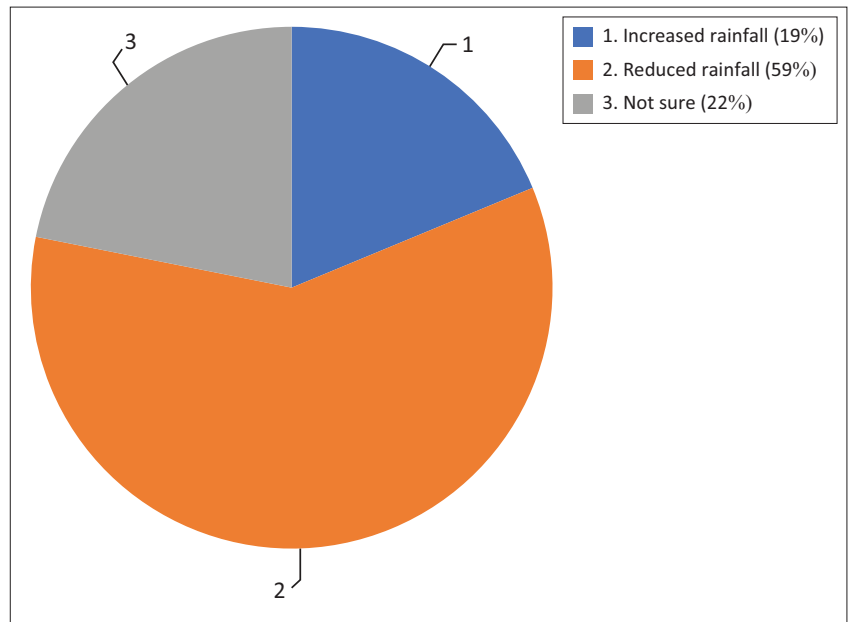

FIGURE 6: Perceptions of climate change impact on rainfall pattern. 
studies, which found that climate change often led to food inflation (Cammaran \& Tian 2018:109).

Other findings were that reduced rainfall activity and amounts had positive effects. For example, the reduced water flow at the waterfall prolonged the seasons of specific activities such as white water rafting and swimming at the Devil's Cataract, which are popular amongst tourists. These findings were also confirmed in a study by Dube and Nhamo (2019b:2036). On the contrary, the observed increase in rainfall activity in 2017 shortened the white water rafting activities at the waterfall. Increased rainfall activity also adversely affected game drives because roads in the national parks become inaccessible. Respondents pointed out that severe rainfall that has become characteristic of the rainy seasons in some years tends to damage roads, which makes it challenging to access some of the areas by road. Other activities that were cited to be averse to intense rainfall activities included helicopter flights over the waterfall. In a broader sense, there was a consensus that good rains mean good 'thunder' water flow at the waterfall, which naturally attracts more tourist visits to the area.

\section{River flow regime}

Half of the respondents indicated that they had witnessed a recession in the Zambezi river flow pattern regime of the river. Successive droughts in the Zambezi Basin in the recent past led to some tourists arguing that the Victoria Falls are drying up in 2014-2015 and part of 2016. About 19\% of respondents (Figure 7) noted that they had witnessed an increase in water

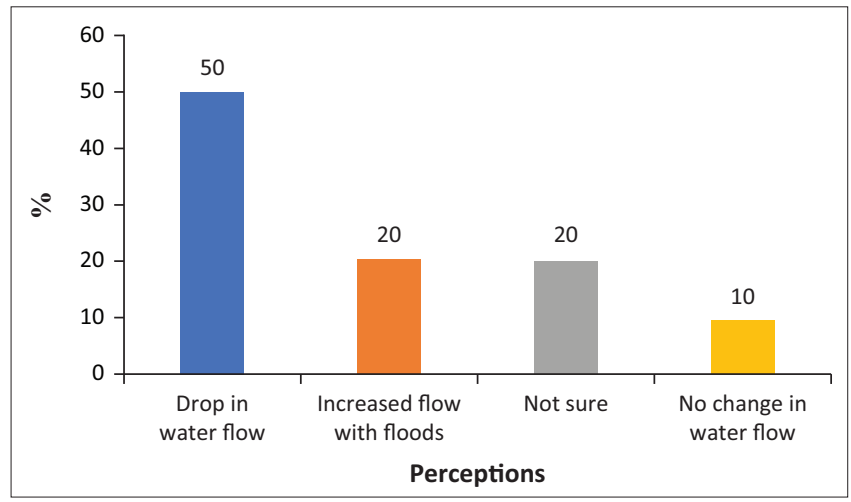

FIGURE 7: Observed changes in water flow patterns at Victoria Falls $(n=77)$. flow with flooding. This can be attributed to extreme rainfall events witnessed in the area during recent years. Significant rainfall variations of water flow have been observed along the Zambezi River over the years (Dube \& Nhamo 2019b:2025). Ten per cent of the respondents said they had not witnessed any changes in the river flow pattern. From the fieldwork, it emerged that the Victoria Falls tourism business community is aware of climate change and is genuinely concerned about the impact of climate change on the resort town.

The respondents were further asked to rate the three pictures of the waterfall from three phases of the waterfall, namely, peak discharge (Figure 8c), mid-peak discharge (Figure $8 \mathrm{~b}$ ) and off-peak discharge (Figure $8 \mathrm{a}$ ). The results indicated that the respondents preferred to see the waterfall at its peak discharge, which is synonymous with full water flow 'the smoke that thunders'. This finding confirms earlier perceptions from the tourists (Dube \& Nhamo 2019b:2037).

From Figure 9, the majority of the tourism role players enjoy seeing Victoria Falls at its peak and mid-peak discharge. That period offers a beautiful spectacle of the waterfall and its associated rainbow. The spray of the water during that period is at its highest with sprays reaching most parts of the Victoria Falls rainforest. In a testament to this, many establishments have lookout points where tourists can view the water spray from a distance and take pictures. Interviews with key stakeholders in the Victoria Falls town confirmed the results by noting that peak water discharge was the most desired state of the waterfall because tourists enjoy walking in the rainforest and hearing the thunder. The local name, Mosi oa Tunya, means the smoke that thunders, which

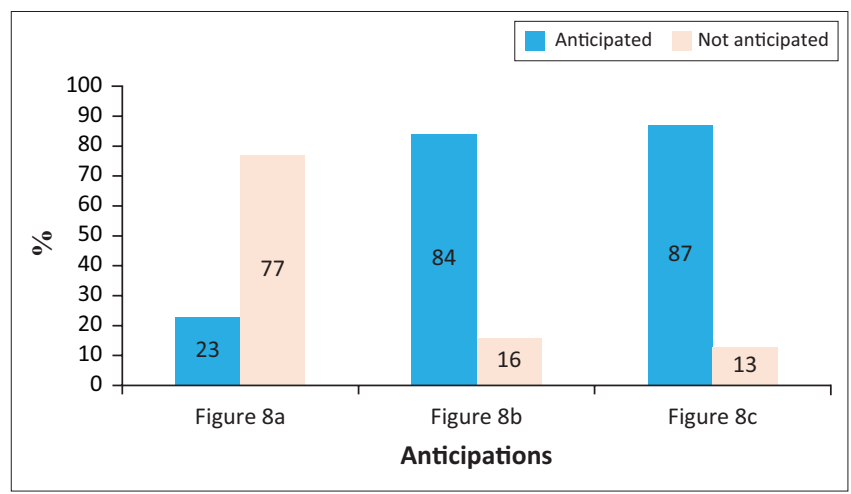

FIGURE 9: The anticipated and least anticipated picture of Victoria Falls ( $n=77$ ).

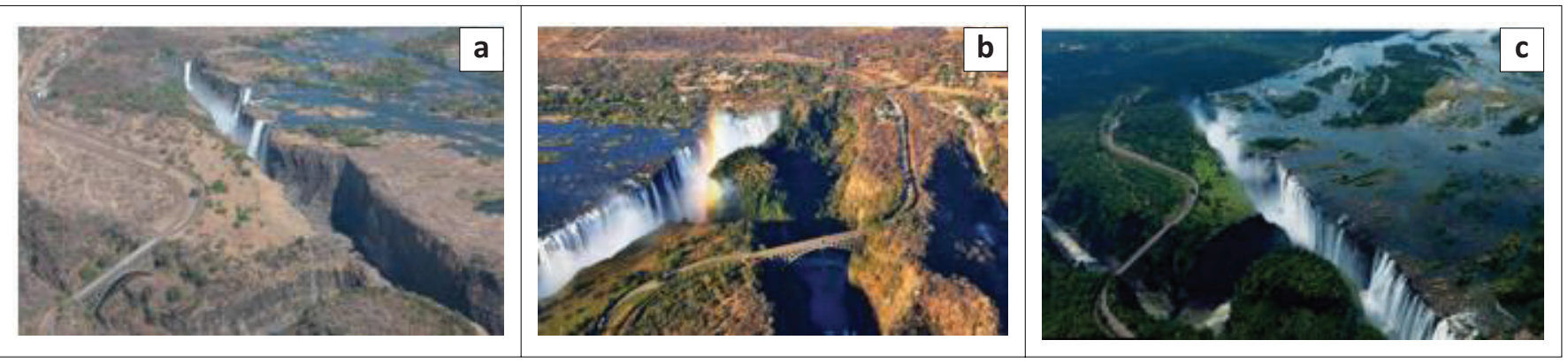

Source: Sun Safaris, 2017, Sun Safaris: Victoria Falls, viewed 12 June 2017, from: https://www.sunsafaris.com/safari/zambia/victoria-falls/

FIGURE 8: Respondents' perceptions on the scene they like to see most at Victoria Falls (a-c). 
further confirms the connection of the peak discharge and the local people.

A small portion indicated that they enjoy seeing the waterfall during the dry season. The argument was that during that period it is easy for tourists to swim, take pictures and enjoy the famous white water rafting along the Zambezi rapids. The stakeholders also noted that during low season animals concentrate on the river banks, making cruises a more attractive and appealing activity for tourists. Low season is also the period water-rafting companies make more money.

\section{Conclusion}

The study examined the tourism business operators' perceptions, knowledge and attitude towards climate change at the Victoria Falls in Zimbabwe. There is a growing concern amongst respondents about the impact of repeated extreme weather events caused by climate change. In as much as there is a consciousness of the adverse impact of climate change on the tourism industry, there are still knowledge gaps on how to adapt and mitigate climate change. To this end, increased awareness and capacity building by governments, civil society and international bodies can go a long way in empowering businesses to mitigate against and adapt to climate change in the resort town. Given the frequency of the droughts and the impact it has on resort reputation, it is recommended that key stakeholders in the resort come up with a clear way of reporting and responding to challenges that occur.

Making climate financing available in the tourism industry is critical. This will allow the industry to move to cleaner technology, which has multiple benefits. These benefits range from savings, to use of efficient technology and a reduction in the carbon footprint of the tourism sector. Streamlining budgets for climate mitigation is also central today in tourism financing to ensure business sustainability. With the growing disruptions from extreme weather events as a consequence of climate change, there is a need to redesign and re-engineer infrastructure with a view of improving tourism resilience. Relooking into insurances can also assist tourism businesses to buffer themselves against the impact of climate change.

Diversification of tourism resorts is a must to ensure viability in cases of severe weather events. Governments need to actively support the industry to ensure its viability, given tourism's centrality to economic development and forex earnings. Policies that ensure the promotion of green tourism will go a long way in reducing the carbon footprint of the tourism industry as self-regulation may not be ideal. The tourism industry needs to assist in research and innovation to keep abreast of international best practice in the sector.

\section{Acknowledgements}

The authors would like to thank the Victoria Falls Business Community and the Victoria Falls Town Council for availing themselves for this research and all the invaluable insights.

\section{Competing interests}

The authors have declared that no competing interests exist.

\section{Authors' contributions}

The two authors worked together on the article from conceptualisation of the article to data collection, analysis and write-up of the entire article.

\section{Funding information}

Funding for this study was obtained from EXXARO Chair for Business and Climate Change University of South Africa (UNISA).

\section{Data availability statement}

Data are available upon request to the author.

\section{Disclaimer}

The views and opinions expressed in this article are those of the authors and do not necessarily reflect the official policy of any affiliated agency or institution.

\section{References}

Becken, S., 2013, 'A review of tourism and climate change as an evolving knowledge domain', Tourism Management Perspectives 6, 53-62. https://doi.org/10.1016/j. tmp.2012.11.006

Becken, S., 2018, 'How tourists and tourism experts perceive climate change and carbon-offsetting schemes', Journal of Sustainable Tourism 12(4), 332-345. https://doi.org/10.1080/09669580408667241

Becken, S. \& Wilson, J., 2013, 'The impacts of weather on tourist travel', Tourism Geographies 15(4), 620-639. https://doi.org/10.1080/14616688.2012.762541

Byg, A. \& Salick, J., 2009, 'Local perspectives on a global phenomenon - Climate change in Eastern Tibetan villages', Global Environmental Change 19(2), 156-166. https://doi.org/10.1016/j.gloenvcha.2009.01.010

Cammaran, D. \& Tian, D., 2018, 'The effects of projected climate and climate extremes on a winter and summer crop in the southeast USA', Agricultural and Forest Meteorology 248, 109-118. https://doi.org/10.1016/j.agrformet.2017.09.007

Dube, K., 2020, 'Tourism and sustainable development goals in the African context', International Journal of Economics and Finance Studies 12(1), 88-102. https://doi. org/10.34109/ijefs.202012106

Dube, K., Mearns, K., Mini, S. \& Chapungu, L., 2018, 'Tourists' knowledge and perceptions on the impact of climate change on tourism in Okavango Delta, Botswana', African Journal of Hospitality, Tourism and Leisure 7(4), 1-18.

Dube, K. \& Nhamo, G., 2018, 'Climate variability, change and potential impacts on tourism: Evidence from the Zambian side of the Victoria Falls', Environmental Science \& Policy 84, 113-123. https://doi.org/10.1016/j.envsci.2018.03.009

Dube, K. \& Nhamo, G., 2019a, 'Climate change and the aviation sector: A focus on the Victoria Falls tourism route', Environmental Development 29, 5-15. https://doi. org/10.1016/j.envdev.2018.12.006

Dube, K. \& Nhamo, G., 2019b, 'Climate change and potential impacts on tourism Evidence from the Zimbabwean side of the Victoria Falls', Environment, Development and Sustainability 21, 2025-2041. https://doi.org/10.1007/s10668018-0118-y

Dube, K. \& Nhamo, G., 2020a, 'Evidence and impact of climate change on South African national parks. Potential implications for tourism in the Kruger National Park', Environmental Development 33, 1-11. https://doi.org/10.1016/j. envdev.2019.100485

Dube, K. \& Nhamo, G., 2020b, 'Tourist perceptions and attitudes regarding the impacts of climate change on Victoria Falls', Bulletin of Geography. Socio-Economic Series 47, 27-44. https://doi.org/10.2478/bog-2020-0002

Dube, K. \& Nhamo, G., 2020c, 'Vulnerability of nature-based tourism to climate variability and change: Case of Kariba resort town, Zimbabwe', Journal of Outdoor Recreation and Tourism 29, 1-13. https://doi.org/10.1016/j.jort.2020.100281

Fitchett, M.J., Grant, B. \& Hoogendoorn, G., 2016, 'Climate change threats to two lowlying South African coastal towns: Risks and perceptions', Climate Change and Tourism 112(5-6), 1-9. https://doi.org/10.17159/sajs.2016/20150262

Friedlingstein, P. et al., 2014, 'Persistent growth of $\mathrm{CO}_{2}$ emissions and implications for reaching climate targets', Nature Geoscience $7(10)$, 709. https://doi.org/10.1038/ ngeo2248 
Georgopoulou, E., Mirasgedis, S., Sarafidis, Y., Hontou, V., Gakis, N. \& Lalas, D.P., 2019, 'Climatic preferences for beach tourism: An empirical study on Greek islands', Theoretical and Applied Climatology 137(1-2), 667-691. https://doi.org/10.1007/ s00704-018-2612-4

Gómez, M., Armesto, L. \& Cors, I., 2017, 'Climate change perception and local adaptation responses: Rural tourism as a case study', Cuadernos de Turismo 39 287-654.

Gössling, S., Bredberg, M., Randow, A., E Sandström, E. \& Svensson, P., 2006, 'Tourist perceptions of climate change: A study of international tourists in Zanzibar', Current Issues in Tourism 9(4-5), 419-435. https://doi.org/10.2167/cit265.0

Gössling, S. \& Scott, D., 2018, 'The decarbonisation impasse: Global tourism leaders' views on climate change mitigation', Journal of Sustainable Tourism 26(12), 2071-2086. https://doi.org/10.1080/09669582.2018.1529770

Gössling, S., Scott, D. \& Hall, C., 2013, 'Challenges of tourism in a low-carbon economy' Wiley Interdisciplinary Reviews: Climate Change 4(6), 525-538. https://doi. org/10.1002/wcc.243

Hambira, W.L., Saarinen, J., Manwa, H. \& Atlhopheng, J.R., 2013, 'Climate change adaptation practices in nature-based tourism in Maun in the Okavango Delta area, Botswana: How prepared are the tourism businesses?', Tourism Review International 17(1), 19-29. https://doi.org/10.3727/154427213X13649094288025

Hemp, A., 2005, 'Climate change-driven forest fires marginalize the impact of ice cap wasting on Kilimanjaro', Global Change Biology 11(7), 1013-1023. https://doi. org/10.1111/j.1365-2486.2005.00968.

Hindley, A. \& Font, X., 2018, 'Values and motivations in tourist perceptions of lastchance tourism', Tourism and Hospitality Research 18(1), 3-14. https://doi. org/10.1177/1467358415619674

Hoogendoorn, G., Grant, B. \& Fitchett, J.M., 2016, 'Disjunct perceptions? Climate change threats in two-low lying South African coastal towns', Bulletin of Geography. Socio-economic Series 31(31), 59-71. https://doi.org/10.1515/bog-2016-0005

Jiang, J., Wang, W., Wang, C. \& Liu, Y., 2017, 'Combating climate change calls for a global technological cooperation system built on the concept of ecological civilization', Chinese Journal of Population Resources and Environment 15, 21-31. civilization', Chinese Journal of Population Resources
https://doi.org/10.1080/10042857.2017.1286145

Kilungu, H., Leemans, R., Munishi, P.K. \& Amelung, B., 2017, 'Climate change threatens major tourist attractions and tourism in Serengeti National Park, Tanzania', in W. Lea Filho, S. Belay, J. Kalangu, W. Menas, P. Munishi, K. Musiyiwa (eds.), Climate change adaptation in Africa, pp. 375-392, Springer, Cham.

Kilungu, H. et al., 2019, 'Forty years of climate and land-cover change and its effects on tourism resources in Kilimanjaro National Park', Tourism Planning \& Development 16(2), 235-253. https://doi.org/10.1080/21568316.2019.1569121

Kimberlin, C.L. \& Winterstein, A.G., 2008, 'Validity and reliability of measurement instruments used in research', American Journal of Health-System Pharmacy 65(23), 2276-2284. https://doi.org/10.2146/ajhp070364

Kourula, A., Pisani, N. \& Kolk, A., 2017, 'Corporate sustainability and inclusive development: Highlights from international business and management research', Sustainability Science 24, 14-18. https://doi.org/10.1016/j.cosust.2017.01.003

Liu, T., Ma, Z., Huffman, T., Ma, L., Jiang, H. \& Xie, H., 2016, 'Gaps in provincial decisionmaker's perception and knowledge of climate change adaptation in China' Environmental Science \& Policy 58, 41-51. https://doi.org/10.1016/j. Environmental Scienc

Marshall, M.N., 1996, 'The key informant technique', Family Practice 13, 92-97. https://doi.org/10.1093/fampra/13.1.92

Matthews, L., Scott, D. \& Andrey, J., 2019, 'Development of a data-driven weathe index for beach parks tourism', International Journal of Biometeorology 2019 1-14. https://doi.org/10.1007/s00484-019-01799-7

Michailidou, A., Vlachokostas, C. \& Moussiopoulos, N., 2016, 'Interactions between climate change and the tourism sector: Multiple-criteria decision analysis to assess mitigation and adaptation options in tourism areas', Tourism Management 55, 1-12. https://doi.org/10.1016/j.tourman.2016.01.010

Mukwada, G. \& Manatsa, D., 2018, 'Is climate change the Nemesis of rural development?: An analysis of patterns and trends of Zimbabwean droughts', in S. Mal, R.B. Singh \& C. Huggel (eds.), Climate change, extreme events and disaster risk reduction, pp. 173-182, Springer, Cham.

Mushawemhuka, W., Rogerson, J.M. \& Saarinen, J., 2018, 'Nature-based tourism operators' perceptions and adaptation to climate change in Hwange National Park, Zimbabwe', Bulletin of Geography. Socio-Economic Series 42(42), 115-127. https://doi.org/10.2478/bog-2018-0034
Nalau, J., Handmer, J. \& Dalesa, M., 2017, 'The role and capacity of government in a climate crisis: Cyclone pam in Vanuatu', in W. Leal Filho (ed.), Climate change adaptation in pacific countries. climate change management, pp. 151-161, Springer, Cham.

Nishijima, D., 2017, 'The role of technology, product lifetime, and energy efficiency in climate mitigation: A case study of air conditioners in Japan', Energy Policy 104 340-347. https://doi.org/10.1016/j.enpol.2017.01.045

Noble, H. \& Smith, J., 2015, 'Issues of validity and reliability in qualitative research', Evidence-Based Nursing 18(2), 34-35

Norander, S. \& Brandhorst, J., 2017, 'Case study', in M. Allen (ed.), The SAGE encyclopedia of communication research methods, pp. 117-119, Sage, Thousand Oaks, CA.

Pandy, W.R., 2017, 'Tourism enterprises and climate change: Some research imperatives', African Journal of Hospitality, Tourism and Leisure 6(4), 1-18.

Pandy, W.R. \& Rogerson, C.M., 2018, 'Tourism and climate change: Stakeholder perceptions of at risk tourism segments in South Africa', EuroEconomica 37(2), 104-118.

Peeters, P. \& Dubois, G., 2010, 'Tourism travel under climate change mitigation constraints', Journal of Transport Geography 18(3), 447-457. https://doi. org/10.1016/j.jtrangeo.2009.09.003

Perry, C.T. \& Morgan, K.M., 2017, 'Bleaching drives collapse in reef carbonate budgets and reef growth potential on southern Maldives reefs', Scientific Reports 7, 1-9. https://doi.org/10.1038/srep40581

Prokopy, L.S. et al., 2016, 'The effects of extreme drought on climate change beliefs, risk perceptions, and adaptation attitudes', Climatic Change 135(2), 211-226. https://doi.org/10.1007/s10584-015-1561-5

Schandl, H. \& Walker, I., 2017, Social science and sustainability, CSIRO Publishing, Clayton South.

Scott, D., 2011, 'Why sustainable tourism must address climate change', Journal of Sustainable Tourism 19(1), 17-34. https://doi.org/10.1080/09669582.2010.53 9694

Scott, D., Hall, C. \& Gössling, S., 2016a, 'A report on the Paris Climate Change Agreement and its implications for tourism: Why we will always have Paris', Journal of Sustainable Tourism 24(1), 8-30. https://doi.org/10.1080/09669582.20 16.1187623

Scott, D., Hall, C.M. \& Gössling, S., 2016b, 'A review of the IPCC Fifth Assessment and implications for tourism sector climate resilience and decarbonization', Journal of Sustainable Tourism 24(1), 8-30. https://doi.org/10.1080/09669582.2015.10 62021

Scott, D., Steiger, R., Rutty, M. \& Fang, Y., 2019, 'The changing geography of the Winter Olympic and Paralympic Games in a warmer world', Current Issues in Tourism 22(11), 1301-1311. https://doi.org/10.1080/13683500.2018.1436161

Seetanah, B., 2011, 'Assessing the dynamic economic impact of tourism for island economies', Annals of tourism research 38(1), 291-308.

Shi, J., Visschers, V., Siegrist, M. \& Arvai, J., 2016, 'Knowledge as a driver of public perceptions about climate change reassessed', Nature Climate Change 6 , 759-763. https://doi.org/10.1038/nclimate2997

Sun Safaris, 2017, Sun Safaris: Victoria Falls, viewed 12 June 2017, from https://www. sunsafaris.com/safari/zambia/victoria-falls/.

Tang, C., Zhong, L. \& Ng, P., 2017, 'Factors that influence the tourism industry's carbon emissions: A tourism area life cycle model perspective', Energy Policy 109, 704-718. https://doi.org/10.1016/j.enpol.2017.07.050

United Nations (UN), 2015, About the sustainable development goals, viewed 28 February 2020, from https://www.un.org/sustainabledevelopment/sustainabledevelopment-goals/.

Wilbanks, T.J., Fernandez, S.J. \& Allen, M.R., 2015, 'Extreme weather events and interconnected infrastructures: Toward more comprehensive climate change planning', Environment: Science and Policy for Sustainable Development 57(4), 4-15. https://doi.org/10.1080/00139157.2015.1048134

Wolff, N.H., Mumby, P.J., Devlin, M. \& Anthony, K., 2018, 'Vulnerability of the Great Barrier Reef to climate change and local pressures', Global Change Biology 24(5), 1978-1991. https://doi.org/10.1111/gcb.14043 